論文

\title{
MOX 燃料再処理における溶媒劣化
}

\section{$P u$ 精製工程における溶媒劣化とその影響}

\author{
川口 芳仁 ${ }^{1}$, 森本 和幸 $1, *$, 北尾 貴彦 1 , 大山 孝一 1 , 大森 栄一 1
}

\author{
Study of Solvent Degradation in Reprocessing MOX Spent Fuel
}

Solvent Degradation and Its Effect on Pu Purification Cycle

\begin{abstract}
Yoshihito KAWAGUCHI ${ }^{1}$, Kazuyuki MORIMOTO ${ }^{1, *}$, Takahiko KITAO ${ }^{1}$, Koichi OHYAMA ${ }^{1}$ and Eiichi OMORI ${ }^{1}$
${ }^{1}$ Tokai Reprocessing technology development center, Nuclear fuel cycle engineering laboratories, Tokai research and development center, Japan Atomic Energy Agency, 4-33 Muramatsu, Tokai-mura, Naka-gun, Ibaraki 319-1194, Japan
\end{abstract}

(Received October 8, 2008 and accepted in revised form April 28, 2009)

\begin{abstract}
A solvent including tributyl phosphate (TBP) has been used for extraction of uranium (U) and plutonium $(\mathrm{Pu})$ from nuclear spent fuel at Tokai Reprocessing Plant (TRP). TBP is said to be degraded by radiolysis, hydrolysis, and reactions catalyzed by extracted elements. One of the problems caused by TBP degradation is transfer of $\mathrm{Pu}$ into $\mathrm{U}$ stream caused by strong chemical binding between $\mathrm{Pu}$ and dibutyl phosphate (DBP), which is a degradation product of TBP. TBP degradation kinetic equations were developed based on degradation experiments using $\mathrm{Pu}$ samples with different alpha-ray emission rates that were taken from actual processes at TRP. The influence of degradation on Pu stripping characteristics was investigated. Diluted nitric acid alone could not readily strip Pu when DBP concentration was on the order of $10^{3} \mathrm{mg} / \mathrm{L}$, but a reduction agent, i.e., $\mathrm{U}$ (IV) with hydrazine, drastically improved the efficiency of Pu stripping. TRP has recently started to reprocess mixed oxide (MOX) spent fuel from the heavy water reactor FUGEN that includes Pu with higher alpha-ray emission. However, DBP concentration was still sufficiently low for stable solvent extraction operation. In addition, even after retention of $\mathrm{Pu}$ in the solvent for 20 days during a temporary suspension of the solvent extraction process, no Pu transfer into U stream was observed.
\end{abstract}

\section{KEYWORDS: TBP, DBP, solvent degradation, TBP degradation kinetic equation, purifica-} tion, solvent extraction, MOX spent fuel, reprocessing

\section{I.はじめに}

東海再処理施設 (Tokai Reprocessing Plant：以下 TRP という)の再処理工程(工程)では，30 vol\%リン酸トリブ チル $(\mathrm{TBP}) / \mathrm{n}$-ドデカン(溶媒) および硝酸を用いたピュー レックス法により, 使用済燃料を再処理している。抽出剤 である TBP は放射線分解, 酸による加水分解等により劣 化し, TBP からリン酸ジブチル $(\mathrm{DBP}), \mathrm{DBP}$ からリン酸 モノブチル $(\mathrm{MBP})$, さらに $\mathrm{MBP}$ からリン酸に分解さ れ，この過程でブタノール $\left(\mathrm{C}_{4} \mathrm{H}_{9} \mathrm{OH}\right)$ も生成する。このう ち DBP 生成量は, MBP やリン酸の生成量に比べて多 く1), 抽出工程に拈いて TBP の劣化物としては DBP が最 も重要である。TBP の劣化 (溶媒劣化)により DBP が生

\footnotetext{
1 独日本原子力研究開発機構

* Corresponding author, E-mail: morimoto.kazuyuki87@jaea.go.jp

成すると, ウラン $(\mathrm{U})$, プルトニウム $(\mathrm{Pu})$ の損失や核分 裂生成物 $(\mathrm{FP})$ の除染係数低下などを引き起こすとされて いる。特に Pu 濃度が高いプルトニウム精製工程において は, $\mathrm{Pu}$ からの $\alpha$ 線 $(\mathrm{Pu}-\alpha)$ による溶媒劣化の傾向が高くな る。溶媒中において DBP と Puが錯体を形成すると, 希 硝酸による溶媒からの $\mathrm{Pu}$ 逆抽出が困難になり，Pu が廃 液側に移行するなど, 使用済燃料からの $\mathrm{Pu}$ 等の分離性能 に影響を及ぼす。なお, ブタノールは水相へ移行し，抽出 操作上問題になることはない。

TRP では2007年からふげん MOX Type B 使用済燃料 (MOX-B 然料)を再処理している2)。この燃料は，これま で再処理してきた低濃縮ウラン軽水炉使用済燃料 (軽水炉 燃料)に比べ， $\alpha$ 崩壊核種である $\mathrm{Pu}-238, \mathrm{Pu}-240$ および $\mathrm{Pu}-242$ の含有量が多く, $\mathrm{Pu}-\alpha$ 比放射能が高いため, 溶 媒を劣化させやすいと考えられる。Fig. 1 に使用済燃料 の $\mathrm{Pu}-\alpha$ 比放射能を示す。これは，ORIGEN 2.2 により算 
出したものである。Fig. 1 の軽水炉燃料は, 燃焼度 28 $\mathrm{GWD} / \mathrm{t}$, 比出力 $35 \mathrm{MW}$, 初期ウラン濃縮度 $4.0 \%$, 冷却 日数180日のものであり, MOX-B 燃料については実照射

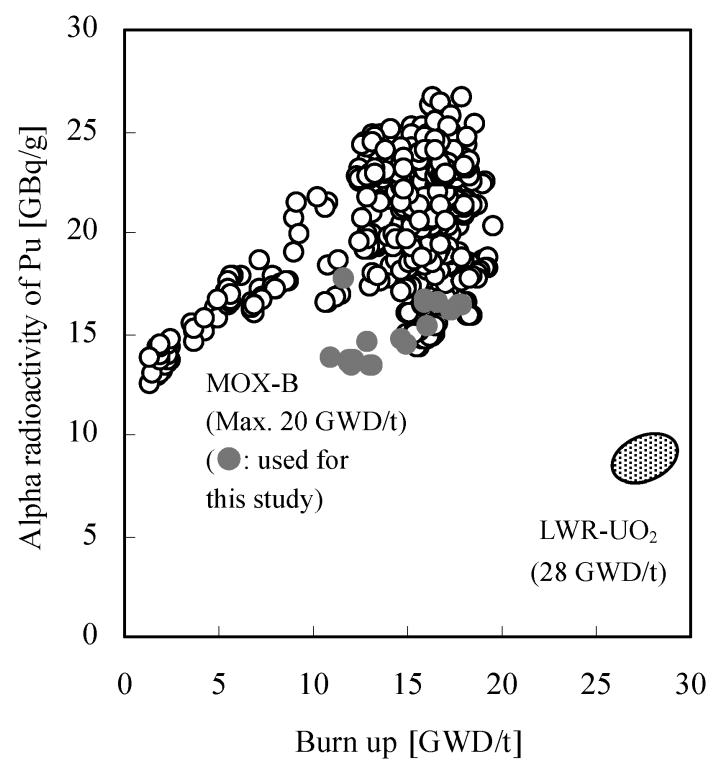

Fig. 1 Alpha radioactivity of $\mathrm{Pu}$ in spent fuel (Calculated with ORIGEN 2.2)
条件, 燃料の製造, 検査結果をもとに算出した。MOX-B 然料の $\mathrm{Pu}-\alpha$ 比放射能のばらつきは, 燃料の初期 $\mathrm{Pu}$ 同位 体組成の違いによるものが主である。

そこで本研究では, 使用済燃料再処理時に抽出器内から 採取した， $\mathrm{Pu}$ を含む $30 \mathrm{vol} \% \mathrm{TBP} / \mathrm{n}$ ードデカン溶液を用 い, $\mathrm{Pu}-\alpha$ による溶媒劣化評価試験として，(1)DBP 濃度の 経時変化を測定し, DBP 生成速度式を算出, また, (2)高 濃度 DBP 溶媒加の $\mathrm{Pu}$ 逆抽出試験を行い, $\mathrm{Pu}$ 逆抽出性 に及ぼす DBP 濃度の影響を把握した。さらに，使用済燃 料再処理時における工程内の調査として, (3) MOX-B 然 料再処理時における抽出器内の DBP 濃度を測定した。ま た, (4)約 20 日間工程停止した状態における抽出器内 DBP 濃度および工程運転再開後の $\mathrm{Pu}$ の廃液側への移行を調査 し, $\mathrm{Pu}$ の逆抽出挙動に対する DBP 濃度の影響を評価した。

\section{II. 工 程 概 要}

Figure 2 にTRPの工程概要を示す。抽出器にはミキ サセトラを用いている。

分離第 1 サイクル工程 (1st cycle) に供給された使用済燃 料の溶解液は, まず $\mathrm{U}, \mathrm{Pu}$ と FPに分離される。分離さ れた Uおよび $\mathrm{Pu}$ は分離第 2 サイクル工程 (2nd cycle)に 供給され, さらに FP を除去した後, U と Puを分離し,

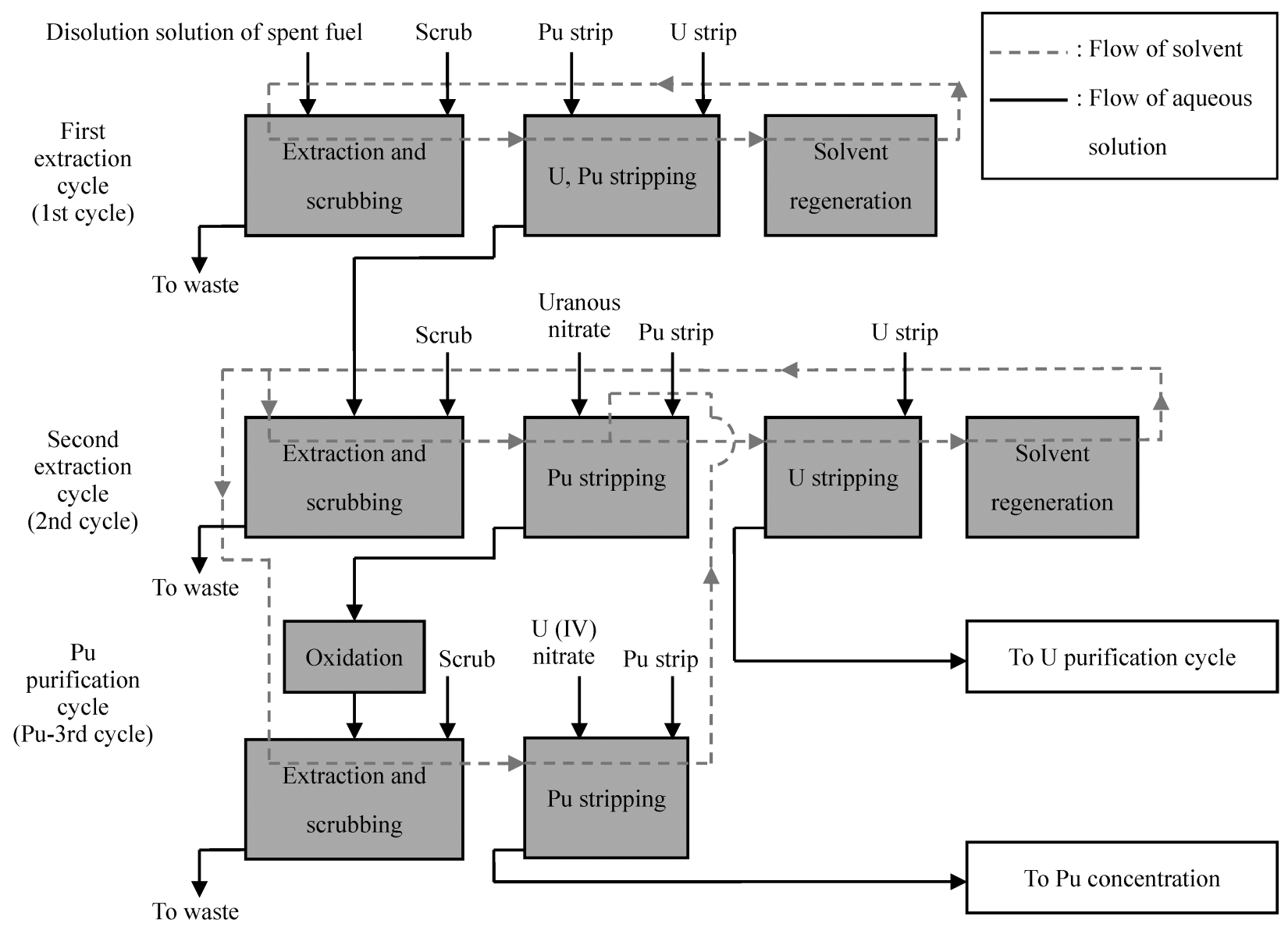

Fig. 2 Extraction process at TRP 
それぞれ，ウラン精製工程 (U-3rd cycle)，プルトニウム 精製工程 $(\mathrm{Pu}-3 \mathrm{rd}$ cycle) に供給される。

Figure 3 に $\mathrm{Pu}-3$ rd cycle 概要図を示す。2nd cycle に て分離された $\mathrm{Pu}(3$ 価) は, 酸化工程に扔いて 4 価に酸化 され, $\mathrm{Pu}-3 \mathrm{rd}$ cycle $の$ 抽出段に供給される。抽出 · 洗浄 段に打いて $\mathrm{Pu}$ は， $30 \% \mathrm{TBP} / \mathrm{n}$-ドデカンに抽出され， ス クラブ液により洗浄された後, $\mathrm{Pu}$ 逆抽出段にて逆抽出さ れ，プルトニウム濃縮工程に供給される。なお， 2nd cycle 抢よび Pu-3rd cycle では, Puの逆抽出のための還 元剂として硝酸ウラナス $\left(\mathrm{U}\left(\mathrm{NO}_{3}\right)_{4}\right)$ を用いている。

溶媒中の DBP は, 炭酸ナトリウム $\left(\mathrm{Na}_{2} \mathrm{CO}_{3}\right)$, 水酸化 ナトリウム $(\mathrm{NaOH})$ を用いて溶媒洗浄器で除去され, 洗浄 後の溶媒は, 再度工程で使用される。なお, 1st cycleで 使用されている溶媒は, 1st cycle 内に設置されている溶 媒洗浄器に扔いて洗浄され, 再び 1st cycle の及で使用さ れるが，Pu-3rd cycle で使用されている溶媒は, Pu 逆抽 出後の溶媒に U が含まれるため, 2nd cycle にリサイクル される。溶媒中の U を U 製品側で回収した後, 溶媒は 2nd cycle に設置されている溶媒洗浄器において洗浄され, 2nd cycle および Pu-3rd cycle で再び使用される。

\section{III. 溶媒劣化評価試験}

\section{DBP 生成速度の算出}

\section{(1) 試験方法}

試料は, Pu-3rd cycle のU および Puを抽出した溶媒 ( $\mathrm{Pu}$ 装荷溶媒) から採取し, 有機相単相の状態でポリエチ レン製容器内において密封保管した。単位時間, 単位体積 当たりの $\mathrm{DBP}$ 生成量 ( $\mathrm{DBP}$ 生成速度) は, $\mathrm{Pu}$ 装荷溶媒中 の DBP 濃度の時間変化から算出した。な抢, 保管してい る試料を攪拌した場合, DBP 生成速度が高くなるという 報告がある3)が，本試験で使用した試料は攪拌していない。

試料は, Fig. 3 に示した Pu-3rd cycle 内のうち Pu 濃度 が高い Pu-3rd-A から採取したものであり, Table 1 に示 す 2 種類の試料を採取した。 $\mathrm{Pu}-\alpha$ 比放射能は $\mathrm{Pu}$ 同位体 組成比, 半減期から算出した。なお, $\mathrm{Pu}-\alpha$ 比放射能の違 いは, 初期 Pu 同位体組成, 燃焼度, 比出力の違いによる ものである。

なお, 試料は室温で保管し, 試料温度は $17 \sim 25^{\circ} \mathrm{C}$ の範 囲で变動した(温度は, DBP 濃度分析時, ポリエチレン製 容器から試料を採取するたびに測定した)。

Table 1 Parameters for Pu loaded solvent

\begin{tabular}{|c|c|c|c|c|c|c|c|c|}
\hline \multirow{2}{*}{$\begin{array}{l}\mathrm{Pu} \text { alpha radioactivity } \\
{[\mathrm{GBq} / \mathrm{gPu}]}\end{array}$} & \multirow{2}{*}{$\begin{array}{l}\mathrm{Pu} \text { concentration } \\
{[\mathrm{g} / \mathrm{L}]}\end{array}$} & \multicolumn{5}{|c|}{$\mathrm{Pu}$ isotope ratio $[\%]$} & \multirow{2}{*}{$\begin{array}{c}\text { Acid } \\
\text { concentration } \\
{[\mathrm{mol} / \mathrm{L}]}\end{array}$} & \multirow{2}{*}{$\begin{array}{l}\text { Specific heat generation } \\
{[\mathrm{W} / \mathrm{L}]^{(* 1)}}\end{array}$} \\
\hline & & ${ }^{238} \mathrm{Pu}$ & ${ }^{239} \mathrm{Pu}$ & ${ }^{240} \mathrm{Pu}$ & ${ }^{241} \mathrm{Pu}$ & ${ }^{242} \mathrm{Pu}$ & & \\
\hline 6.9 & 4.00 & 0.4 & 60.7 & 33.0 & 2.9 & 3.0 & 0.46 & 0.024 \\
\hline 15 & 3.87 & 1.7 & 46.5 & 38.5 & 4.5 & 8.8 & 0.42 & 0.051 \\
\hline
\end{tabular}

${ }^{(* 1)}$ Calculated using alpha radiolytic energy of Pu given in JAERI Review 2001-038, p. 4404).

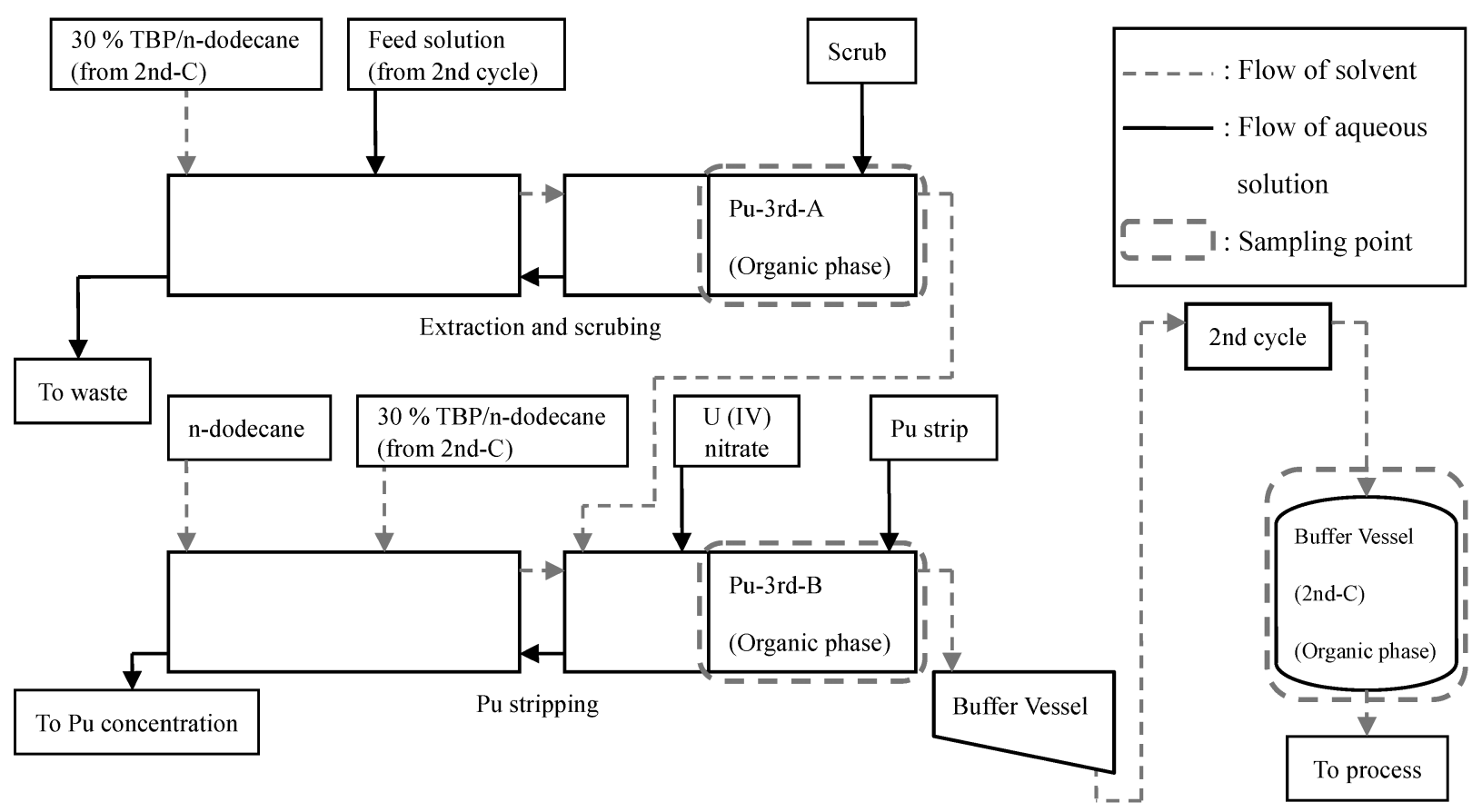

Fig. 3 Schematic diagram of $\mathrm{Pu}$ purification cycle ( $\mathrm{Pu}-3 \mathrm{rd}$ cycle) 


\section{(2) DBP 濃度分析方法}

DBP 濃度分析にはフーリエ变換赤外分光光度計 (FTIR，日本分光侏製 FT/IR-660)を用いた。

DBP 濃度の分析手順概要を Fig. 4 に示す。なお, 試料 セルは，日本分光秼製 $\mathrm{KRS}-5$ (1.0 mm)を用いた。

測定試料はポリエチレン製容器内に保管しておいた試料 から分取し，Fig. 4 に示す手順によりDBP 濃度を分析し た。DBP 濃度分析は， 1 試料につき 2 回実施した。な お，分析精度は $5 \%$ である。

本研究では, DBP の C-O-P 結合の C-O 伸縮における 赤外吸収 $\left.\left(1030 \mathrm{~cm}^{-1}\right)^{5}\right)$ から, DBP 濃度を算出しているが, TBP および DBP ともに C-O-P 結合をもっているため, TBP $と \mathrm{DBP}$ が十分に分離できていない場合, DBP 濃度 が過大に評価される。TBPとDBPを高い分離能で分離

Take organic sample into separating funnel

Add dilute $\mathrm{NaOH}$ to the organic sample and stir the sample. (to separate DBP from organic sample)
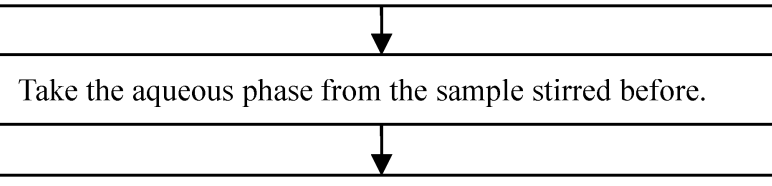

Add carbon tetrachloride to the sample and stir it. And remove the organic phase. (to remove TBP from aqueous sample)

Stir the aqueous sample with adding $\mathrm{HNO}_{3}$. (to extract DBP to carbon tetrachloride easily)
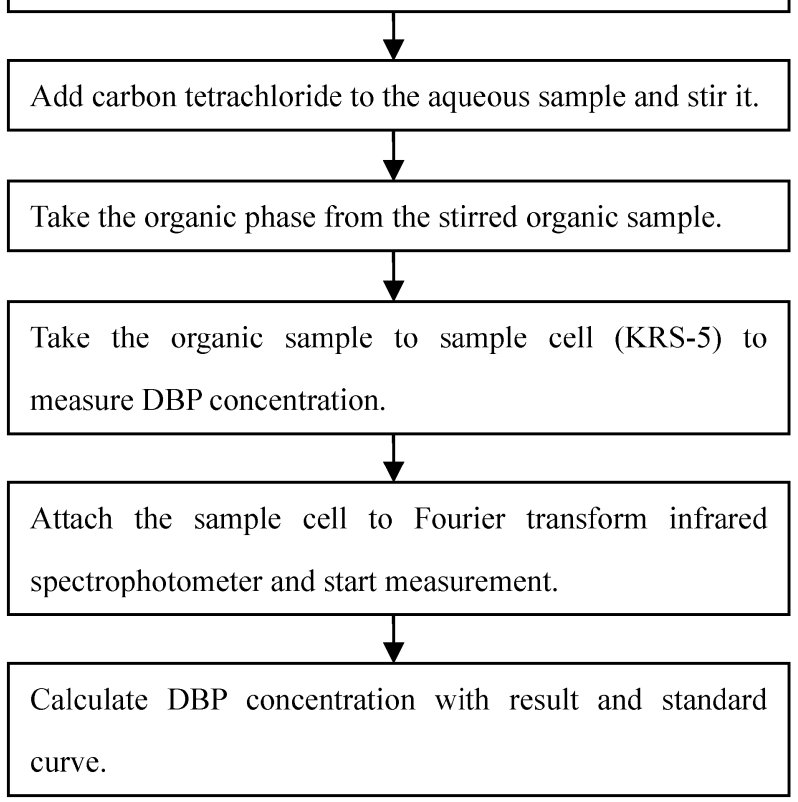

Fig. 4 Flow chart for DBP analysis
するため, 分析の前処理として試料に $\mathrm{NaOH}$ を加え, HDBPをNaDBP とし，有機相と水相にそれぞれTBP と NaDBP を分離した。このうち水相のみ分取し, 硝酸を加 え NaDBPをHDBP とした後, HDBPを四塩化炭素によ って抽出し, 四塩化炭素中の DBP 濃度を測定した。な お，この前処理による DBP の回収率は $91 \%$ であり, 本試 験で測定した DBP 濃度は補正後の值である。

また,この DBP 濃度分析方法は, 後述する高濃度 $\mathrm{DBP}$ 溶媒からの $\mathrm{Pu}$ 逆抽出試験および工程調查にも適用 した。

\section{(3) 試験結果}

Figure 5 に測定した DBP 濃度の時間変化を示す。試験 は約 1,500 時間実施し, この間, 各試料の DBP 濃度は, 時間の経過とともに, 直線的に上昇している。 $\mathrm{Pu}-\alpha$ 比放 射能 $6.9 \mathrm{GBq} / \mathrm{g}$ の試料の直線の傾きは $1.59 \mathrm{mg} /(\mathrm{L} \cdot \mathrm{h})$ $(0.024 \mathrm{~W} / \mathrm{L}), 15 \mathrm{GBq} / \mathrm{g}$ の試料の傾きは $2.98 \mathrm{mg} /(\mathrm{L} \cdot \mathrm{h})$ (0.051 W/L)である。

DBP 生成要因は, 放射線分解, 酸による加水分解以外 に, イオン触媒による加水分解がある1)。イオン触媒によ る加水分解は, 全 DBP 生成量のうち, その元素からの放 射線分解による DBP 生成量と酸による加水分解に起因す る DBP 生成量を除いたものである。

本試験において, 試料中の元素のほとんどが Uおよび $\mathrm{Pu}\left(\mathrm{U}\right.$ 濃度約 $7 \mathrm{~g} / \mathrm{L}, \mathrm{Pu}$ 濃度約 $4 \mathrm{~g} / \mathrm{L}$ 。MIXSET-X $\left.{ }^{6}\right)$ によ る計算值)であるが, 放射線分解に寄与する放射線は $\mathrm{Pu}-$ $\alpha$ のとする。これは, 工程内の U の約 $100 \%$ が長半減期 の U-238 であり, $\mathrm{Pu}$ と比較し比放射能が十分低いこと, また， $\mathrm{Pu}$ は $\alpha$ 線， $\beta$ 線打よび $\gamma$ 線を放出するが，各放射 線の吸収エネルギーの割合は， $\alpha$ 線が約 $95 \%, \beta$ 線が約 5

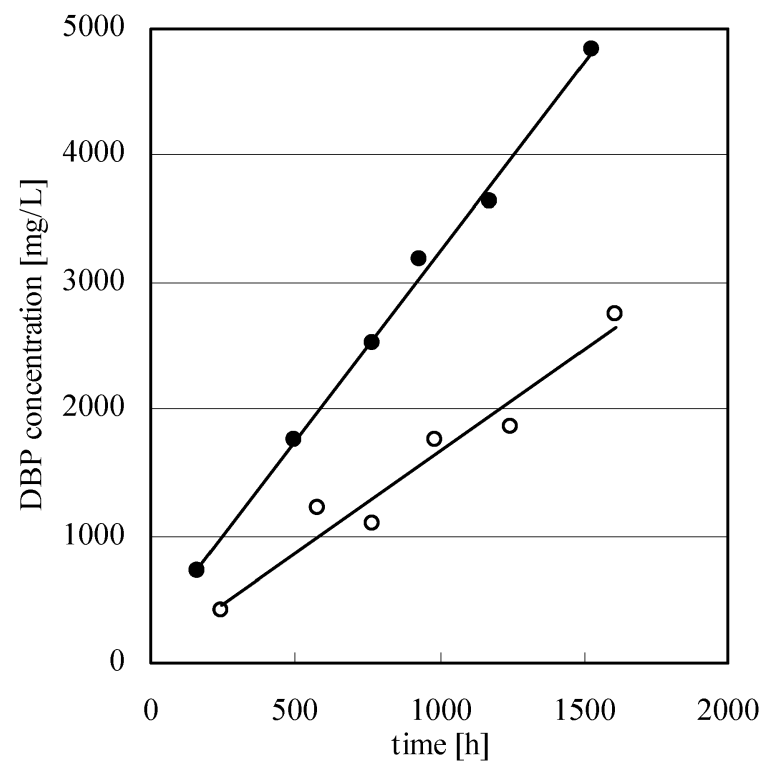

Fig. 5 DBP concentration in Pu loaded solvent as a function of time
(○ : $6.9 \mathrm{GBq} / \mathrm{g}, \quad: 15 \mathrm{GBq} / \mathrm{g})$. 
$\%, \gamma$ 線はほぼ $0 \%$ (各放射線の平均エネルギーから算出 した)であることによる。

また，イオン触媒として考慮する元素は $\mathrm{Pu}$ の久とす る。これは, 工程内の元素が $\mathrm{U}(\mathrm{U}$ 濃度約 $85 \mathrm{~g} / \mathrm{L}(\mathrm{MIX}$ SET-X による計算值) )のみである U-3rd cycle に掞いて は， DBP 濃度が $2.0 \times 10^{1} \mathrm{mg} / \mathrm{L}$ 未満であり，DBP はほと んど生成していないことから，TBPの放射線分解抢よび イオン触媒による加水分解について，Uはほとんど寄与 していないと考えられるためである。また，本試験時間に おける $\mathrm{Pu}$ 元素による $\mathrm{DBP}$ 生成速度は，以下の理由によ り一定であると考えられる。(1)全 DBP 濃度の時間変化が 直線であること，(2)本試験条件ではTBP 濃度に比べ DBP 濃度が低く, TBP 中の DBP が飽和状態でないこと, (3)試験時間に比べ $\mathrm{Pu}$ の半減期が長く, 放射線による影響 が時間に対して一定であること，(4)本試験時間(約 1,500 時 間)における酸の加水分解による DBP 生成速度は一定で あると考えられる5゙こと。

\section{DBP 生成速度式の作成}

\section{(1) Lloyd らの式}

Lloyd らは，Pu装荷溶媒中に生成した $\mathrm{Pu}-\mathrm{DBP}$ 錯体の 濃度を測定により求め,（1) 式に異なる試験条件におけ る $\mathrm{Pu}$ 濃度, 溶媒の吸収線量および酸による加水分解に起 因する $\mathrm{Pu}-\mathrm{DBP}$ 錯体生成量を代入することにより（1 ) 式 中の係数を算出し, $\mathrm{Pu}$ 装荷溶媒中における各要因の溶媒 劣化寄与割合を明らかにした1)。

$$
P u_{T}=P u_{A}+P u_{R} \cdot D+P u_{C} \cdot C \quad[g]
$$

$P u_{T}$ : 全 $\mathrm{Pu}-\mathrm{DBP}$ 錯体生成量 $[\mathrm{g}]$

$P u_{A}$ : 酸による加水分解に起因する $\mathrm{Pu}-\mathrm{DBP}$ 錯体生成 量 $[\mathrm{g}]$

$P u_{R}: \mathrm{Pu}-\alpha$ による放射線分解に関する係数 $[\mathrm{g} /(\mathrm{Wh} / \mathrm{L})]$

$D$ : 溶媒の吸収線量 $[\mathrm{Wh} / \mathrm{L}]$

$P u_{C}$ : 金属イオンにより誘発される加水分解に関する係 数 $[\mathrm{g} /(\mathrm{g} / \mathrm{L})]$

$C \quad: \mathrm{Pu}$ 濃度 $[\mathrm{g} / \mathrm{L}]$

(1) 式の右辺第 2 項 $P u_{R} \cdot D$ は放射線分解による $\mathrm{Pu}-$ DBP 錯体生成量を, 第 3 項 $P u_{C} \cdot C$ は $\mathrm{Pu}$ イオン触媒によ る $\mathrm{Pu}-\mathrm{DBP}$ 錯体生成量を示している。

\section{（2）DBP 生成速度式}

まず，放射線分解による DBP 生成速度は，次式で表さ れる。

$$
\begin{aligned}
& R=G \times W \times K \quad[\mathrm{mg} /(\mathrm{L} \cdot \mathrm{h})] \\
& R \quad: \text { 放射線分解による } \mathrm{DBP} \text { 生成速度 }[\mathrm{mg} /(\mathrm{L} \cdot \mathrm{h})] \\
& G: \mathrm{DBP} \text { 生成 } \mathrm{G} \text { 值 }[\text { 個 } / 100 \mathrm{eV}] \\
& W: \text { 単位体積当たりの発熱量 }[\mathrm{W} / \mathrm{L}] \\
& K \text { : 係数 }[100 \mathrm{eV} \cdot \mathrm{mg} /(\mathrm{W} \cdot \mathrm{h})](=M \times 1000 \times 60 \times 60 /
\end{aligned}
$$

$$
\left.100 e N_{A}=78.8\right)
$$$$
M: \mathrm{DBP} \text { 分子量 }[-](=210)
$$$$
\text { e }: 1.60 \times 10^{-19}[\mathrm{~J} / \mathrm{eV}]
$$$$
N_{A}: \text { アボガドロ定数 }[-]\left(=6.02 \times 10^{23}\right)
$$

次に，Puイオン触媒による DBP 生成速度については, $\mathrm{DBP}$ 生成速度が $\mathrm{Pu}$ 濃度の一次に比例すると仮定する と, 次式で表される。

$$
I=a[P u] \quad[\mathrm{mg} /(\mathrm{L} \cdot \mathrm{h})]
$$

I : $\mathrm{Pu}$ イオン触媒による $\mathrm{DBP}$ 生成速度 $[\mathrm{mg} /(\mathrm{L} \cdot \mathrm{h})]$

$a \quad:$ 定数 $[\mathrm{mg} /(\mathrm{h} \cdot \mathrm{g})]$

$[P u]: \mathrm{Pu}$ 濃度 $[\mathrm{g} / \mathrm{L}]$

また，酸による加水分解に起因する DBP 生成速度につ

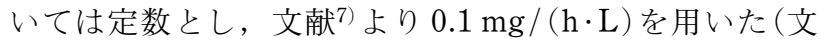
献7)の試験結果を外挿すると, 本試験の試料温度 $(17 \sim 25$ $\left.{ }^{\circ} \mathrm{C}\right)$ に打ける DBP 生成速度は約 $0.05 \sim 0.13 \mathrm{mg} /(\mathrm{h} \cdot \mathrm{L})$ で ある（溶媒中の酸濃度 : $0.2 \sim 0.8 \mathrm{~mol} / \mathrm{L}$ )。

$$
H=0.1 \quad[\mathrm{mg} /(\mathrm{L} \cdot \mathrm{h})]
$$

$H$ : 酸による加水分解に起因する DBP 生成速度 $[\mathrm{mg} /$ $(\mathrm{L} \cdot \mathrm{h})]$

放射線分解による DBP 生成, Puイオン触媒による $\mathrm{DBP}$ 生成, 酸による加水分解に起因する DBP 生成が独 立して生じるものと仮定すると，（2），（3），（4 )式よ り, 全 DBP 生成速度 $\mathrm{T}[\mathrm{mg} /(\mathrm{L} \cdot \mathrm{h})]$ は，次式で表される。

$$
\begin{aligned}
T & =R+I+H \\
& =G \cdot W \cdot K+a[P u]+0.1 \quad[\mathrm{mg} /(\mathrm{L} \cdot \mathrm{h})] \\
T: & \text { 全 } \mathrm{DBP} \text { 生成速度 }[\mathrm{mg} /(\mathrm{L} \cdot \mathrm{h})]
\end{aligned}
$$

この式は Lloyd ら1)が示した式と同様であるが，それぞ れの要因における試料中の DBP 生成量を示している彼ら の式と異なり，1 時間当たりに増加する DBP 濃度を示し ている。このため, 抽出器内で生成する $\mathrm{DBP}$ 濃度を算出 でき，工程運転管理に反映できると考えられる。

\section{（３）DBP 生成速度式における各係数の算出}

DBP 生成速度の算出で得られた結果から，（5)式の各 係数を算出した。

試験で用いた各 $\mathrm{Pu}$ 装荷溶媒の発熱密度， $\mathrm{Pu}$ 濃度，ま た, 試験で得られた全 DBP 生成速度と文献の酸による加 水分解に起因寸る DBP 生成速度を( 5 ) 式に代入し，2 の連立方程式を解くことによって， $G$ 抢よび $a$ は以下の ように算出される。

$$
\begin{aligned}
& G=0.65 \\
& a=0.06
\end{aligned}
$$


したがって，DBP 生成速度式は次式で表される。

$$
\begin{aligned}
T & =G \cdot W \cdot K+a[P u]+0.1 \\
& =0.65 \times 78.8 W+0.06[P u]+0.1 \\
& =51.2 W+0.06[P u]+0.1 \quad[\mathrm{mg} /(\mathrm{L} \cdot \mathrm{h})]
\end{aligned}
$$

ただし, ( 6 ) 式の適用範囲は, 有機相中の酸濃度が $0.2 \sim 0.8 \mathrm{~mol} / \mathrm{L}$ ，温度が $17 \sim 25^{\circ} \mathrm{C}$ の場合である。

この結果より, 放射線分解, $\mathrm{Pu}$ イオン触媒による加水 分解, 酸による加水分解に起因するそれぞれの溶媒劣化寄 与割合は，（6 )式に発熱密度および $\mathrm{Pu}$ 濃度を代入するこ とにより, $R: I: H=89: 8: 3$ (発熱密度 $: 0.051 \mathrm{~W} / \mathrm{L}$, $\mathrm{Pu}$ 濃度 : $3.87 \mathrm{~g} / \mathrm{L}$ ), $78: 15: 7$ (発熱密度 : $0.024 \mathrm{~W} / \mathrm{L}$, $\mathrm{Pu}$ 濃度 : $4.00 \mathrm{~g} / \mathrm{L})$ となり, 全 DBP のうち約 8〜約 9 割 は, TBP の放射線分解により生成することがわかる。ま た, $\mathrm{Pu}$ イオン触媒による加水分解および酸による加水分 解の影響が小さいことを示唆している。

これは, $\mathrm{Pu}$ イオン触媒による加水分解が約 5 割占める という Lloyd ら 1)の報告と異なるが, 彼らの実験では, 試

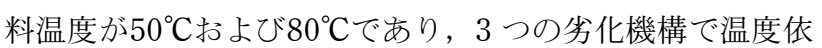
存性が異なることが主な原因と考えられる。今後, Pu 濃 度, 試料温度等をパラメータとした試験を実施し, この相 違について確認する必要がある。

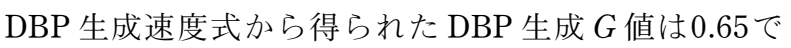
ある。また, 文献によると, DBP 生成 $G$ 值は $\alpha$ 線による ものと $\gamma$ 線によるものとでは, 差がほとんどみられず4), $\mathrm{DBP}$ 生成 $\mathrm{G}$ 值は, $0.51\left(25 \pm 5^{\circ} \mathrm{C}, \gamma \text { 線 }\right)^{8)}, 0.70$ (常温, $\alpha$ 線 $)^{9)}$ という值が報告されており, 本試験結果は, 文献值 と同等の值が得られている。

\section{（4）DBP 生成速度式の検証}

工程停止時の $\mathrm{Pu}-3 \mathrm{rd}-\mathrm{A} の \mathrm{DBP}$ 濃度と作成した DBP 生成速度式から算出した DBP 濃度を比較した。工程停止 時間は477時間であり, そのときの抽出器内 DBP 濃度は $2.2 \times 10^{3} \mathrm{mg} / \mathrm{L}$ であった。工程停止時の DBP 濃度につい ての詳細は, IV-2 節に示す。なお, 抽出器内の $\mathrm{Pu}$ 装荷 溶媒の組成は, Table 1 の $\mathrm{Pu}-\alpha$ 比放射能 $15 \mathrm{GBq} / \mathrm{g}$ の のである。

( 6 ) 式に発熱密度および $\mathrm{Pu}$ 濃度を代入 $($ Table 1 より発 熱密度 $0.051 \mathrm{~W} / \mathrm{L}, \mathrm{Pu}$ 濃度 $3.87 \mathrm{~g} / \mathrm{L})$ すると, $\mathrm{DBP}$ 生成 速度式により算出した DBP 濃度は $1.4 \times 10^{3} \mathrm{mg} / \mathrm{L}$ とな り, 工程停止時の DBP 濃度分析值 $\left(2.2 \times 10^{3} \mathrm{mg} / \mathrm{L}\right)$ の約 0.64 倍であった。

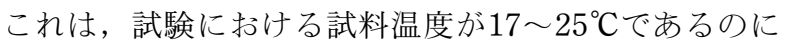
対し, 工程停止時の抽出器内温度が $34 \sim 36^{\circ} \mathrm{C}$ であり, 抽 出器内の温度では $G$ 值, $\mathrm{Pu}$ イオン触媒による加水分解, 酸による加水分解に起因する影響が大きくなるため, DBP 濃度の計算值と分析值に差が生じたと考えられる。 また, $\mathrm{DBP}$ 生成速度式は有機相中の $\mathrm{Pu}$ によるのであ り, 実工程の抽出器においては, 水相中の $\mathrm{Pu}$ による溶媒
Add nitric acid to sample as the volume ratio become organic phase: aqueous phase $=1: 3$.

Then Stir the sample.

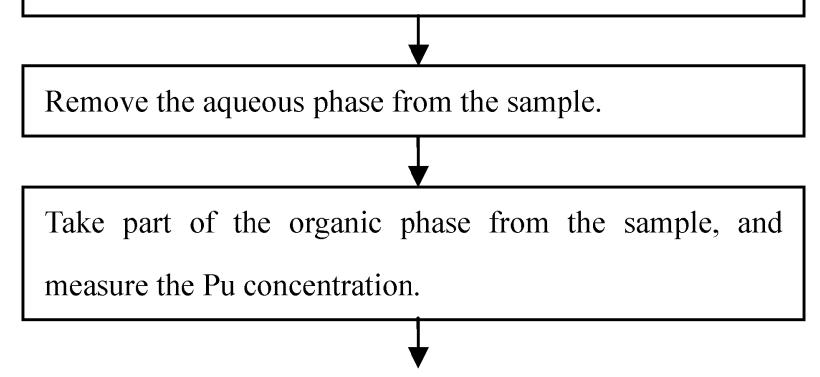

Run the operation mentioned above more two times.

Fig. 6 Flow chart of Pu stripping test

劣化の寄与があることも要因として考えられる。なお (6) 式は, 今後ともデータを蓄積し, 検証していくこと とする。

\section{3. 高濃度 $\mathrm{DBP}$ 溶媒からの $\mathrm{Pu}$ 逆抽出試験}

\section{(1) 試験方法}

Figure 6 に試験手順フローを示す。

試験は, 高濃度の DBP を含む $\mathrm{Pu}$ 装荷溶媒と $0.1 \mathrm{~mol} /$ $\mathrm{L}$ 硝酸溶液の混合接触を繰返し, 溶媒中に残留した Pu 濃 度を測定することにより実施し, 溶媒中の DBP 濃度と逆 抽出後における溶媒中の $\mathrm{Pu}$ 濃度の関係を調査した。さら に, $\mathrm{DBP}$ 濃度 $4.8 \times 10^{3} \mathrm{mg} / \mathrm{L}$ の高濃度 DBP 溶媒は, 0.1 $\mathrm{mol} / \mathrm{L}$ 硝酸の代わりに硝酸ウラナス溶液 $\left(\mathrm{HNO}_{3}: 1.0\right.$ $\left.\mathrm{mol} / \mathrm{L}, \mathrm{U}^{4+}: 7.4 \mathrm{~g} / \mathrm{L}, \mathrm{N}_{2} \mathrm{H}_{4}: 5.3 \mathrm{~g} / \mathrm{L}\right)$ を使用した試験 も実施した。

試験に用いた試料は, DBP 生成速度の算出で用いた $\mathrm{Pu}-\alpha$ 比放射能 $15 \mathrm{GBq} / \mathrm{g}$ のもの゙ある。

試験は, 試料中の DBP 濃度が, $1.8 \times 10^{3} \mathrm{mg} / \mathrm{L}, 3.2 \times$ $10^{3} \mathrm{mg} / \mathrm{L}, 4.8 \times 10^{3} \mathrm{mg} / \mathrm{L}$ の高濃度 DBP 溶媒を用いて実 施した。なお， DBP と $\mathrm{Pu}$ のモル比は, DBP : $\mathrm{Pu}=1$ 〜 $2: 1^{1,10)}$ と考えられる。

\section{（2）試験結果}

Figure 7 に $\mathrm{Pu}$ 逆抽出後の溶媒中の $\mathrm{Pu}$ 濃度を示す。逆 抽出に希硝酸のみを用いた場合, 溶媒中にDBP が含まれ ないときは, 3 回の逆抽出操作でほぼ全量の $\mathrm{Pu}$ が逆抽出 される(MIXSET-X による計算)。DBP 濃度が $1.8 \times 10^{3}$ $\mathrm{mg} / \mathrm{L}$ の溶媒では約 $76 \%, 3.2 \times 10^{3} \mathrm{mg} / \mathrm{L}$ の溶媒では約 37 $\%, 4.8 \times 10^{3} \mathrm{mg} / \mathrm{L}$ の溶媒では約 $4 \%$ の $\mathrm{Pu}$ しか逆抽出さ れず， DBP 濃度が $4.8 \times 10^{3} \mathrm{mg} / \mathrm{L}$ 程度では， $\mathrm{Pu}$ がほとん ぞ逆抽出されないことがわかる。これは, 溶媒中で $\mathrm{Pu}$ と DBP の強固な錯体が形成されるためといわれている。

一方ウラナスを添加した場合, DBP 濃度が $4.8 \times 10^{3}$ $\mathrm{mg} / \mathrm{L}$ であっても, 逆抽出後の溶媒中の $\mathrm{Pu}$ 濃度は定量下 
限値未満となり，ほぼ全量逆抽出された。これらより，ウ ラナスを還元剤として用いる場合, 溶媒劣化が著しく進行 しても，Puの逆抽出上問題がないことがわかる。

このように, 溶媒劣化が進行し, DBP 濃度が $1.0 \times 10^{3}$ $\mathrm{mg} / \mathrm{L}$ のオーダになると, 希硝酸のみでは溶媒からの $\mathrm{Pu}$ 逆抽出が困難になるが，還元剂を用いた場合は，問題なく

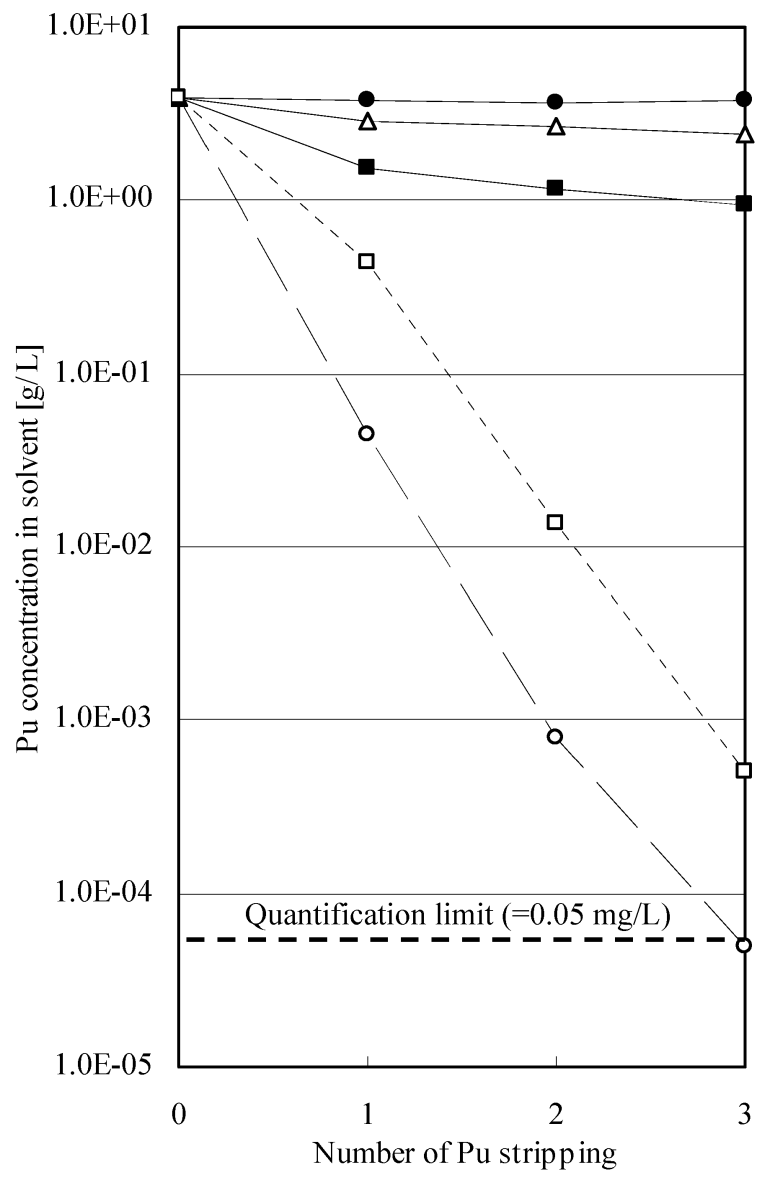

Fig. $7 \mathrm{Pu}$ concentration in solvent after Pu stripping test (Initial $\mathrm{Pu}$ concentration in solvent was $3.87 \mathrm{~g} / \mathrm{L}$, - $\mathrm{DBP}=1.8 \times 10^{3} \mathrm{mg} / \mathrm{L} \quad$ (stripped with $0.1 \mathrm{~mol} / \mathrm{L}$ $\left.\mathrm{HNO}_{3}\right), \triangle \mathrm{DBP}=3.2 \times 10^{3} \mathrm{mg} / \mathrm{L} \quad$ (stripped with 0.1 $\mathrm{mol} / \mathrm{L} \mathrm{HNO}_{3}$ ), $\mathrm{DBP}=4.8 \times 10^{3} \mathrm{mg} / \mathrm{L}$ (stripped with $\left.0.1 \mathrm{~mol} / \mathrm{L} \mathrm{HNO}_{3}\right), \square$ : calculated with MIXSET-X on the assumption that DBP concentration was $0 \mathrm{mg} / \mathrm{L}$ (stripped with $0.1 \mathrm{~mol} / \mathrm{L} \quad \mathrm{HNO}_{3}$ ), $\bigcirc \mathrm{DBP}=4.8 \times 10^{3}$ $\mathrm{mg} / \mathrm{L}$ (stripped with $0.1 \mathrm{~mol} / \mathrm{L} \mathrm{HNO}_{3}, 200 \mathrm{~g} / \mathrm{L} \mathrm{U}^{4+}$ and $\left.5.3 \mathrm{~g} / \mathrm{L} \mathrm{N}_{2} \mathrm{H}_{4}\right)$ ).
$\mathrm{Pu}$ を逆抽出できることがわかった。

\section{IV. 工 程 調 査}

\section{MOX-B 燃料再処理時の抽出器内 DBP 濃度調査}

\section{(1) 調査方法}

MOX-B 燃料再処理時における $\mathrm{Pu}-3 \mathrm{rd}$ cycle 内 $\mathrm{DBP}$ 濃 度を調査した。調査は, Fig. 3 に示した Pu 濃度が高い抽 出器 $(\mathrm{Pu}-3 \mathrm{rd}-\mathrm{A}), \mathrm{Pu}-3 \mathrm{rd}$ の溶媒出口である抽出器 $(\mathrm{Pu}-$ 3rd-B)の溶媒を採取し実施した。また，Pu-3rd cycleに 供給される溶媒中の DBP 濃度は, 溶媒貯槽 (2nd-C)の $\mathrm{DBP}$ 濃度により確認した。

試料採取は, $\mathrm{DBP}$ 濃度, $\mathrm{Pu}$ 濃度等が定常状態 (平衡状 態)に達する工程運転開始後 24 時間以上経過した後に実施 し, 運転パラメータ(供給液, 溶媒, スクラブ液, ストリ ップ液, ウラナスの流量) は一定に保持した。

調査時に再処理した燃料の $\mathrm{Pu}-\alpha$ 比放射能は, 約 15 $\mathrm{GBq} / \mathrm{g}$ である。

\section{(2) 調査結果}

Figure 8 に MOX-B然料再処理時における $\mathrm{Pu}-3 \mathrm{rd}$ cycle の DBP 濃度を示す。DBP 濃度は, $\mathrm{Pu}-3 \mathrm{rd}-\mathrm{A}$ にお いて $4.5 \times 10^{1} \mathrm{mg} / \mathrm{L}, \mathrm{Pu}-3 \mathrm{rd}-\mathrm{B}$ において $1.0 \times 10^{2} \mathrm{mg} / \mathrm{L}$, 2nd-Cにおいて $2.0 \times 10^{1} \mathrm{mg} / \mathrm{L}$ 未満であった。また, 廃 液側への $\mathrm{Pu}$ の移行はなく, 溶媒中の DBP は溶媒洗浄器 において十分除去されており，Pu精製運転上問題はなか った。

\section{2. 工程停止時における抽出器内 DBP 濃度調查}

\section{(1) 調査方法}

試料は Fig. 3 の Pu-3rd-A にて, 工程停止後212時間後, 477時間後に採取し, 溶媒中の DBP 濃度を測定した。さ らに, 工程停止後, 運転再開時におけるUおよび $\mathrm{Pu} の$ 廃液側への移行を調査した。試料中の $\mathrm{Pu}-\alpha$ 比放射能は, $15 \mathrm{GBq} / \mathrm{g}$ ものである。

\section{(2) 抽出器内 DBP 濃度分析結果}

Table 2 に工程停止時に抢ける抽出器内 DBP 濃度を示 す。DBP 濃度は, 工程停止後 212 時間で $9.2 \times 10^{2} \mathrm{mg} / \mathrm{L}$, 工程停止後 477 時間で $2.2 \times 10^{3} \mathrm{mg} / \mathrm{L}$ であった。

なお，工程再開後 24 時間経過後の 2 nd-C における DBP 濃度は $2.0 \times 10^{1} \mathrm{mg} / \mathrm{L}$ 未満であり, 工程内の $\mathrm{DBP}$ は溶媒 洗浄器において十分除去されていることがわかった。

Table 2 DBP concentration in and after process suspension

\begin{tabular}{|c|c|c|c|}
\hline \multirow{2}{*}{ Type of fuel } & \multicolumn{2}{|c|}{ DBP concentration } & \multirow{2}{*}{$\begin{array}{c}\text { Leakage of } \mathrm{U} \text { and } \mathrm{Pu} \\
\text { to waste after } \\
\text { process suspension }\end{array}$} \\
\hline & during process suspension (at $\mathrm{Pu}-3 \mathrm{rd}-\mathrm{A}$ ) & after process suspension (at 2 nd-C) & \\
\hline MOX spent fuel & $\begin{array}{l}9.2 \times 10^{2} \mathrm{mg} / \mathrm{L} \\
(212 \mathrm{~h} \text { later after process was suspended }) \\
2.2 \times 10^{3} \mathrm{mg} / \mathrm{L} \\
(477 \mathrm{~h} \text { later after process was suspended) }\end{array}$ & $\begin{array}{l}<2.0 \times 10^{1} \mathrm{mg} / \mathrm{L} \\
(24 \mathrm{~h} \text { later after process restarted })\end{array}$ & less than quantification limit \\
\hline
\end{tabular}




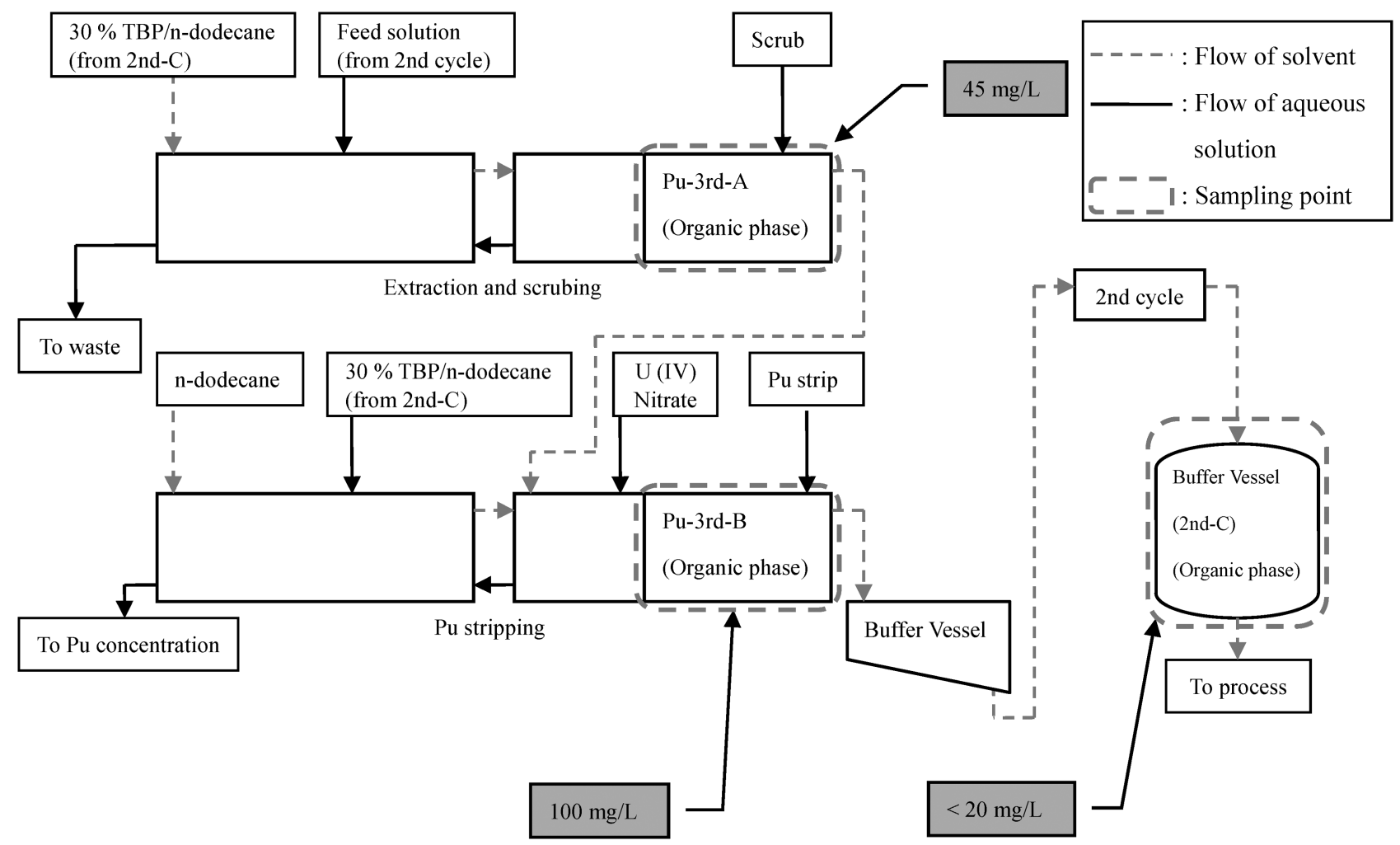

Fig. 8 DBP concentration in Pu purification cycle ( $\mathrm{Pu}-3 \mathrm{rd}$ cycle)

\section{（3）工程運転再開後の影響}

工程運転再開時の抽出器内 DBP 濃度が比較的高濃度で あることから, 運転再開後, 抽出器出口において, U お よび $\mathrm{Pu}$ の廃液側への移行の有無を調査した。その結果, 運転再開後 1 時間後, 2 時間後, 3 時間後における廃液中 の $\mathrm{U}$ および $\mathrm{Pu}$ 濃度は，それぞれ $0.01 \mathrm{~g} / \mathrm{L}$ 未満， 0.05 $\mathrm{mg} / \mathrm{L}$ 未満 (ともに定量下限值未満) であり, U および $\mathrm{Pu}$ の廃液側への移行はなかった。

還元剂を用いる場合， $\mathrm{Pu}$ 逆抽出試験により， DBP 濃度 が $4.8 \times 10^{3} \mathrm{mg} / \mathrm{L}$ 程度まで劣化した溶媒でも $\mathrm{Pu}$ 逆抽出に 問題がないことが確認されており，実際の工程 $(\mathrm{Pu}-3 \mathrm{rd}$ cycle)に拈いても，DBP 濃度が $2.2 \times 10^{3} \mathrm{mg} / \mathrm{L}$ 以下の場 合, 廃液側への $\mathrm{U}$ および $\mathrm{Pu}$ の移行を防止する点では, 問題ないことが確認された。

\section{V.まとめ}

本試験において得られた結果は以下のとおりである。

（1） $\mathrm{Pu}$ 装荷溶媒中の DBP 生成速度式は，次式で表さ れる。（溶媒中の酸濃度 : $0.2 \sim 0.8 \mathrm{~mol} / \mathrm{L}$ ，溶媒と $\mathrm{Pu}$ の接触時間 : 1,500 時間以下, 試料温度 : $17 \sim 25^{\circ} \mathrm{C}$ )

$$
\begin{aligned}
& T=51.2 W+0.06[P u]+0.1 \\
& T \quad: \text { 全 } \mathrm{DBP} \text { 生成速度 }[\mathrm{mg} /(\mathrm{L} \cdot \mathrm{h})] \\
& W \quad: \text { 単位体積当たりの発熱量 }[\mathrm{W} / \mathrm{L}] \\
& {[P u]: \mathrm{Pu} \text { 濃度 }[\mathrm{g} / \mathrm{L}]}
\end{aligned}
$$

(2) $\mathrm{DBP}$ 生成 $G$ 值は，0.65であった。（試料温度は $17 \sim 25^{\circ} \mathrm{C}$, 有機相での $G$ 值)

（3）全 DBP 生成量のうち約 8～約 9 割は，TBP の放射 線分解に起因することがわかった。

（4）溶媒劣化が進行し， DBP 濃度が $1.0 \times 10^{3} \mathrm{mg} / \mathrm{L}$ の オーダになると，希硝酸のみでは溶媒からの $\mathrm{Pu}$ 逆抽 出が困難になるが，還元剤を用いた場合は，問題なく $\mathrm{Pu}$ を逆抽出できることがわかった。

（5）通常運転時において， $\mathrm{Pu}-\alpha$ 比放射能が $15 \mathrm{GBq} / \mathrm{g}$ の $\mathrm{MOX}-\mathrm{B}$ 燃料再処理では, 抽出器内の DBP 濃度は $1.0 \times 10^{2} \mathrm{mg} / \mathrm{L}$ と低く, $\mathrm{Pu}$ 精製運転上の問題は生じ なかった。

（6）約20日間の工程停止時において生成した DBP 濃度 は2.2× $10^{3} \mathrm{mg} / \mathrm{L}$ であり, 工程運転再開後, Uおよび $\mathrm{Pu}$ の廃液側への移行を防止する点では, 問題は生じ なかった。

\section{一参考文献一}

1) M. H. Lloyd, R. L. Fellows, Alpha Radiolysis and Other Factors Affecting Hydrolysis of Tributyl Phosphate, ORNL/TM9565, Oak Ridge National Laboratory (1985).

2) K. Taguchi, S. Nagaoka, A. Yamanaka et al., "MOX Reprocessing at Tokai Reprocessing Plant," Advanced nuclear fuel cycles and systems (GLOBAL 2007), Boise-Idaho (United States), Sep. 9-13, 2007 (2007).

3) L. Stieglitz, W. Ochsenfeld, H. Schmieder, "Der Einfluß, der 
Radiolyse von Tributylphosphat auf die Plutoniumausbeute im Purexprozeß bei hohem Plutoniumgehalt," KFK 691, GESELLSCHAFT FÜR KERNFORSCHUNG 111. B.H., Karlsruhe (1968).

4) 燃料サイクル安全工学部, 再処理プロセス・化学ハンドブッ ク, JAERI-Review 2001-038, 日本原子力研究所 (2001).

5) W. W. Schulz, J. D. Navratil, Science and Technology of Tributyl Phosphate, CRC Press, Inc. (1984).

6）内藤大志, 須藤俊幸, 麻川和宏, 他, 抽出計算コード（MIXSET-X), JNC-TN8400 99-005, 核燃料サイクル開発機構 (1999).

7) E. K. Dukes, The Formation and Effects of Dibutyl Phosphate in Solvent Extraction, DP-250, Du Pont de Nemours (E.I.) \& Co. Savannah River Lab., Augusta, Ga. (1957).

8) Z. Nowak, Radiolytic Degradation of Extractant-Diluent Systems Used in the PUREX Process, 22, 2, Nukleonika (1977).

9) T. Ladrielle, P. Wanet, D. Lemaire et al., "Alpha and gamma induced radiolysis of tributyl-phosphate," J. Radioanal. Nucl. Chem., 59, 355-364 (1983).

10) M. V. Vladimirova, D. A. Fedoseev, I. A. Boikova et al., "Radiation-chemical behavior of actinoids in extraction systems. 2. Pu (IV) $+\mathrm{U}(\mathrm{VI})$ in solution of $30 \% \mathrm{TBP}+n$-dodecane in gamma-radiolysis," Sov. Radiochem., 26, 29-36 (1984). 